Review

\title{
Enzymatic Synthesis and Characterization of Different Families of Chitooligosaccharides and Their Bioactive Properties
}

\author{
Noa Miguez ${ }^{1}$, Peter Kidibule ${ }^{2}$, , Paloma Santos-Moriano ${ }^{1,3}$, Antonio O. Ballesteros ${ }^{1}$, Maria Fernandez-Lobato ${ }^{2}(\mathbb{D}$ \\ and Francisco J. Plou 1,*(D) \\ 1 Instituto de Catálisis y Petroleoquímica, CSIC, 28049 Madrid, Spain; noa.miguez@csic.es (N.M.); \\ palomacarmen.santos@universidadeuropea.es (P.S.-M.); a.ballesteros@icp.csic.es (A.O.B.) \\ 2 Centro de Biología Molecular Severo Ochoa (CSIC-UAM), Departamento de Biología Molecular, Universidad \\ Autónoma de Madrid, 28049 Madrid, Spain; pkidibule@cbm.csic.es (P.K.); mfernandez@cbm.csic.es (M.F.-L.) \\ 3 Department of Health Sciences, Faculty of Biomedical and Health Sciences, Universidad Europea de Madrid, \\ Villaviciosa de Odón, 28670 Madrid, Spain \\ * Correspondence: fplou@icp.csic.es
}

check for

updates

Citation: Miguez, N.; Kidibule, P.; Santos-Moriano, P.; Ballesteros, A.O.; Fernandez-Lobato, M.; Plou, F.J.

Enzymatic Synthesis and

Characterization of Different Families of Chitooligosaccharides and Their Bioactive Properties. Appl. Sci. 2021, 11, 3212. https://doi.org/10.3390/ app11073212

Academic Editor: Carl Grey

Received: 12 March 2021

Accepted: 1 April 2021

Published: 3 April 2021

Publisher's Note: MDPI stays neutral with regard to jurisdictional claims in published maps and institutional affiliations.

Copyright: (c) 2021 by the authors. Licensee MDPI, Basel, Switzerland. This article is an open access article distributed under the terms and conditions of the Creative Commons Attribution (CC BY) license (https:// creativecommons.org/licenses/by/ $4.0 /)$.

\begin{abstract}
Chitooligosaccharides (COS) are homo- or hetero-oligomers of D-glucosamine (GlcN) and N-acetyl-D-glucosamine (GlcNAc) that can be obtained by chitosan or chitin hydrolysis. Their enzymatic production is preferred over other methodologies (physical, chemical, etc.) due to the mild conditions required, the fewer amounts of waste and its efficiency to control product composition. By properly selecting the enzyme (chitinase, chitosanase or nonspecific enzymes) and the substrate properties (degree of deacetylation, molecular weight, etc.), it is possible to direct the synthesis towards any of the three COS types: fully acetylated ( $f a \mathrm{COS})$, partially acetylated ( $p a \mathrm{COS})$ and fully deacetylated $(f d C O S)$. In this article, we review the main strategies to steer the COS production towards a specific group. The chemical characterization of COS by advanced techniques, e.g., high-performance anion-exchange chromatography with pulsed amperometric detection (HPAECPAD) and MALDI-TOF mass spectrometry, is critical for structure-function studies. The scaling of processes to synthesize specific COS mixtures is difficult due to the low solubility of chitin/chitosan, the heterogeneity of the reaction mixtures, and high amounts of salts. Enzyme immobilization can help to minimize such hurdles. The main bioactive properties of COS are herein reviewed. Finally, the anti-inflammatory activity of three COS mixtures was assayed in murine macrophages after stimulation with lipopolysaccharides.
\end{abstract}

Keywords: sustainable chemistry; biocatalysis; aminopolysaccharides; chitin; chitosan; chitooligosaccharides; chitinases; chitosanases; bioactive oligosaccharides; $\mathrm{N}$-acetyl-glucosamine

\section{Introduction}

Chitin, an aminopolysaccharide composed of N-acetyl-D-glucosamine (GlcNAc) units linked by $\beta(14)$ bonds, is the second most abundant polymer in nature and can be found in fungal cell walls and the exoskeletons of arthropods (crustaceans, mollusks, insects, etc.) [1]. Total or partial deacetylation of chitin yields chitosan, a cationic polysaccharide is consisting of variable amounts of D-glucosamine (GlcN) and GlcNAc moieties [2]. In general, when the degree of acetylation of the polymer surpasses 30\%, it is considered chitin, and if it is lower than $30 \%$, it is considered chitosan [3]. To minimize the waste derived from chitin's chemical deacetylation, the development of chitin deacetylases (EC 3.5.1.41) offers a greener alternative [4].

Both chitin and chitosan exhibit an interesting range of physicochemical and biological properties with numerous applications to the food, cosmetic, agriculture, textile and biomedical industries [5,6]. However, their use is often limited by their viscosity and poor aqueous solubility. 
Chitooligosaccharides (COS), the hydrolyzed products of chitin or chitosan, are homoor hetero-oligomers of GlcN and/or GlcNAc linked by $\beta(1 \rightarrow 4)$ bonds $[7,8]$. Generally, COS has a degree of polymerization (DP) up to 20 and an average molecular weight (MW) lower than $3.9 \mathrm{kDa}$. They are water-soluble and possess many interesting biological activities [9-14]. Unlike chitosan, COS can be absorbed in the gastrointestinal tract and enter the bloodstream [15]. The biodegradability of chitosan and their derivatives has been correlated with the presence in human tissues of lysozyme, a glycosyl hydrolase that can hydrolyze $\beta(1 \rightarrow 4)$ linkages in these molecules [16]. COS are high value-added products with great potential in many areas, including agriculture, cosmetics, functional foods, pharmacy and medicine [13,17-19].

According to their composition, COS can be classified into three different types (Figure 1) [20]: fully acetylated chitooligosaccharides ( $f a C O S$ ) (composed exclusively of GlcNAc residues), partially acetylated chitooligosaccharides ( $p a \mathrm{COS}$ ) (formed by GlcN and GlcNAc units), and fully deacetylated chitooligosaccharides ( $f d C O S$ ) (composed of GlcN residues only). Interestingly, COS can exhibit different degrees of polymerization (DP), degrees of deacetylation (DD) and patterns of acetylation (PA), which results in different biological properties [2]. COS obtained by hydrolysis of chitin or chitosan are heterogeneous mixtures of products, which explains the poor reproducibility and divergent results when their biological properties are tested. Hence, the preparation of well-depicted COS is necessary for a better understanding of their biological properties and the analysis of structure-activity relationships and decipher the molecular mechanisms behind them [3].

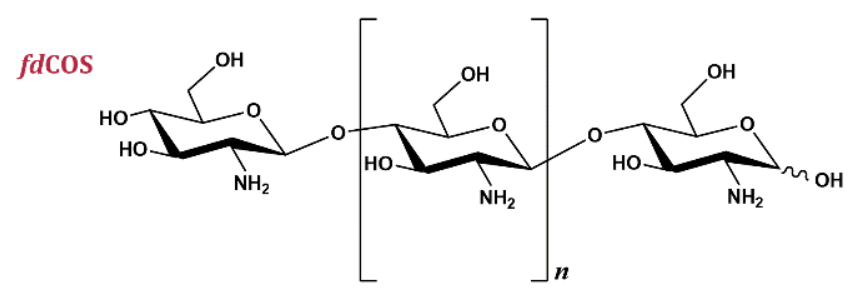

pacos

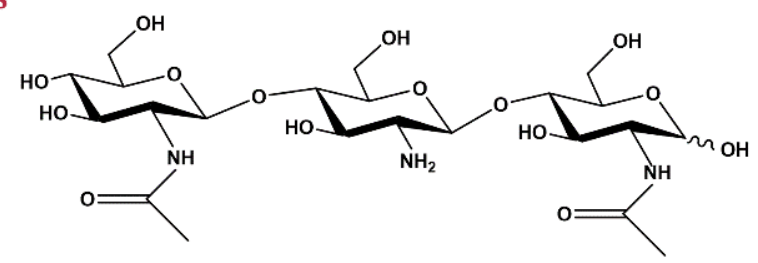

facos

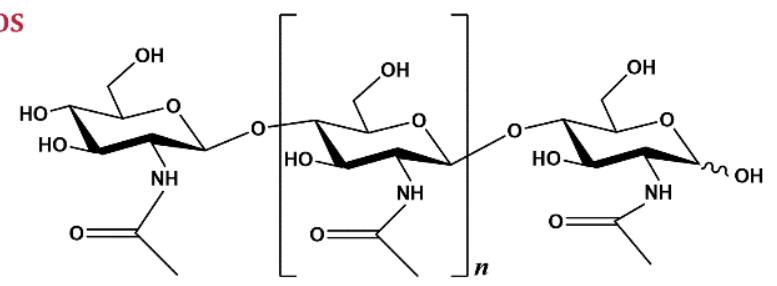

Figure 1. Types of chitooligosaccharides (COS): fully deacetylated (fdCOS), partially acetylated $(p a \mathrm{COS})$ and fully acetylated ( $f a \mathrm{COS})$.

This review is focused on the different approaches for the enzymatic preparation of $\mathrm{COS}$, their characterization, and the influence of $\mathrm{COS}$ composition on their anti-inflammatory properties.

\section{Chitooligosaccharides Production}

Several technological approaches employed for the preparation of COS are summarized in Figure 2. The production of COS can be achieved by physical, chemical and enzymatic methods or a combination of them. 


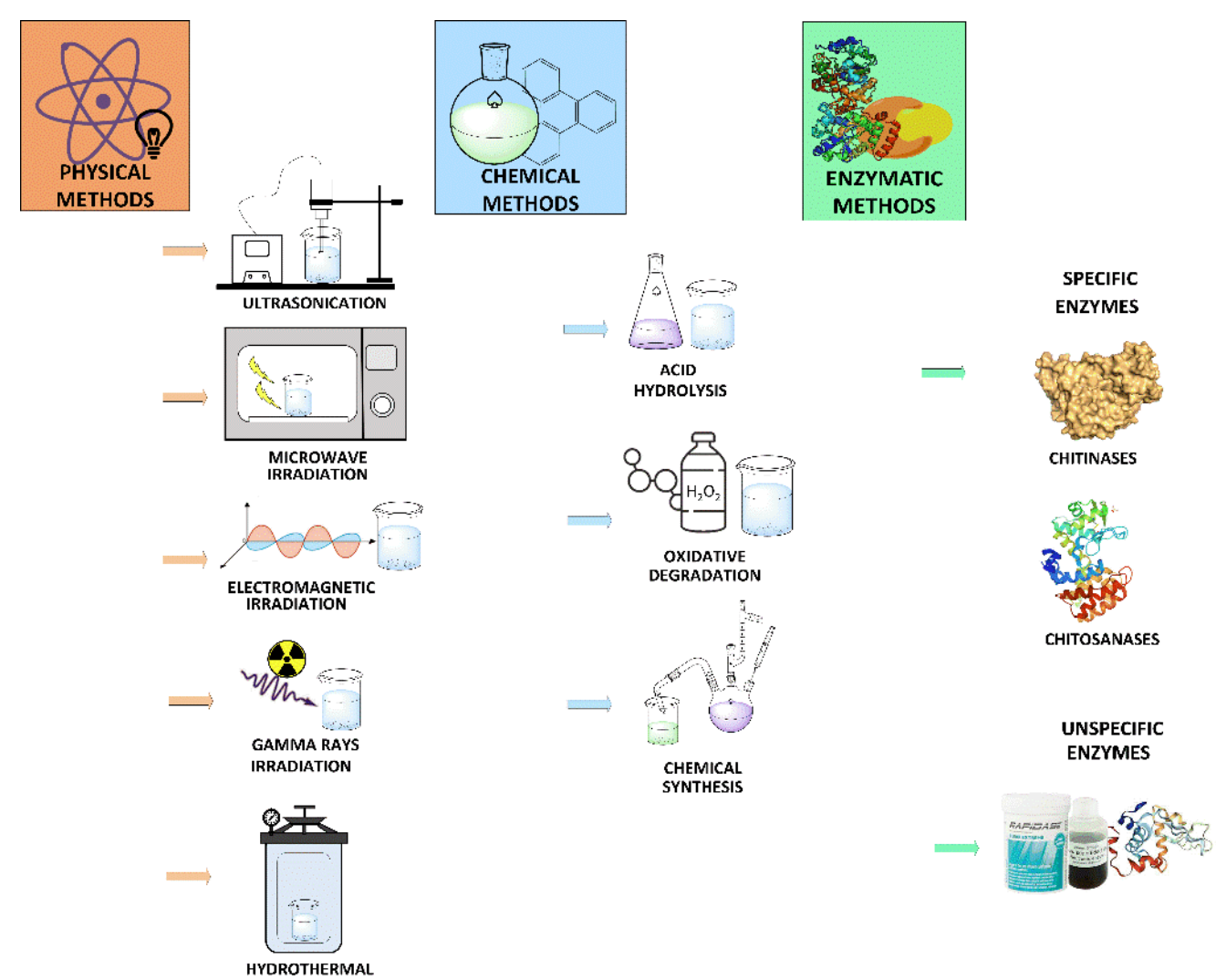

Figure 2. Methodologies for the preparation of chitooligosaccharides.

Physical methods for chitin or chitosan hydrolysis include ultrasonication, hydrothermal treatment, hydrodynamic cavitation, and electromagnetic, gamma rays or microwave irradiation [21-23]. However, these methods have been scarcely investigated and are not well-suited for producing well-defined COS mixtures.

Chemical procedures for COS preparation comprise degradative methods, such as chitin or chitosan depolymerization by acid hydrolysis or oxidation, and chemical synthesis strategies. Acid hydrolysis is the most employed method for COS production at an industrial scale and involves the use of hydrochloric acid, nitrous acid, phosphoric acid or hydrogen fluoride [24]. The oxidative-reductive depolymerization is also widely applied and generally relies on the use of hydrogen peroxide, persulfate or sodium nitrite [25]. Both alternatives give rise to heterogeneous COS mixtures with typically low degrees of polymerization. In addition, they are environmentally risky and generate detrimental byproducts that make COS not suitable for human consumption due to possible contamination and toxicity. Chemical methods for the synthesis of COS have progressed substantially in the last decades, but they usually result in low yields and may require protection/deprotection steps and the use of hazardous chemicals [26].

Enzymatic production of COS is very attractive since it requires milder conditions (relatively low temperatures and slightly acidic $\mathrm{pH}$ ) and does not generate harmful byproducts or wastes [27], which makes it safer and more environmentally friendly approach [28]. In addition, strategies based on biocatalysis present a higher efficiency and allow easier control of the product composition due to inherent enzyme specificity. However, the physicochemical properties of the substrate substantially affect the chemical composition of the final product.

Enzymatic depolymerization of chitin or chitosan can be catalyzed by several glycoside hydrolases (GHs), including specific enzymes, such as chitinases $[29,30]$ and chitosanases [31,32], as well as nonspecific enzymes like other glycosidases (cellulases, glycanases, pectinases, muramidase, etc.), proteases, and lipases [16,33,34]. 
Chitinases (EC 3.2.1.14) occur in families GH18, GH19 and GH20 [35] and are able to hydrolyze GlcNAc-GlcNAc linkages [36,37]. Family GH18 comprises bacterial and fungal chitinases [38], while family GH19 mainly contains plant chitinases. Chitinases can be classified, according to their mode of action, into three major groups: (1) endo-chitinases, (2) exo-chitinases and (3) $\beta$-N-acetylglucosaminidases. Glycosidases belonging to families GH18 and GH19 are considered endo-chitinases since they catalyze the depolymerization of chitin. Family GH20 only includes exo-chitinases and $\beta$-N-acetylglucosaminidases. COS production requires the action of endo-chitinases, whereas $\mathrm{N}$-acetyl-glucosamine preparation entails the use of exo-chitinases and $\beta-\mathrm{N}$-acetylglucosaminidases. Chitinases are also capable of hydrolyzing both GlcNAc-GlcN and GlcN-GlcNAc linkages, enabling chitosan depolymerization, although to a lesser extent than chitosanases. GH18 chitinases require a GlcNAc moiety at subsite -1 [39], whereas GH19 chitinases have no necessity for GlcNAc at this subsite. For this reason, chitinases belonging to family GH18 give rise to COS with GlcNAc residues at their reducing ends [40]. On the other hand, oligomers produced by $\mathrm{GH} 19$ chitinases can present $\mathrm{N}$-acetylated or deacetylated reducing ends.

Chitosanases (EC 3.2.1.132) belong to the families GH5, GH7, GH8, GH46, GH75 and GH80 [41] and are commonly found in soil microbes (both bacteria and fungi) [20,42]. According to their cleavage sites, chitosanases can be classified into two main categories: endo-chitosanases, which are employed for COS production; and exo-chitosanases, which cleave glucosamine residues from the nonreducing end of the substrate. Considering their specificity, three subclasses of chitosanases can be distinguished: (1) chitosanases comprised in class I can carry out the hydrolysis of both GlcNAc-GlcN and GlcN-GlcN bonds; (2) class II chitosanases exclusively cleave GlcN-GlcN linkages; (3) chitosanases belonging to class III can split both GlcN-GlcNAc and GlcN-GlcN linkages [43]. Although the yields reported for the hydrolysis of chitosan by chitosanases are notable, the development of more efficient strains that produce these enzymes constitutes a challenge $[3,44]$.

Besides chitinases and chitosanases, other nonspecific enzymes have shown the ability to recognize glycosidic bonds of chitin and/or chitosan and hydrolyze them [45], although the activity can be one or two orders of magnitude lower than the obtained with specific enzymes [17]. Among these enzymes, most studies have been carried out with other glycosidic enzymes, mostly glycosidases (cellulases, lysozyme, pectinases, amylases, etc.), but also with proteases and lipases [31,33]. However, most of these enzyme preparations are not purified and derive from organisms that could produce chitosanolytic enzymes. Thus, it cannot be discarded that in the case of enzymes of very different nature (e.g., proteases, lipases, amylases, etc.), the presence of a contaminant enzyme is, in fact, responsible for the activity [46]. Nevertheless, commercial preparations have several advantages, including availability, lower cost, and the approval for employment in food processes. Although some nonspecific enzymes give rise to a limited degradation of chitosan, the synergistic action of these enzymes with specific chitosanases can favor COS preparation with a narrow size distribution [3]. More recently, lytic chitin monooxygenases (LPMOs, EC 1.14.99.53) are being investigated as auxiliary enzymes for COS synthesis, as they can break down $\beta(1 \rightarrow 4)$ bonds in crystalline chitin by oxidation, thus facilitating the attack by chitinases [47].

In addition, a few chitosanases and GH18 chitinases have shown a certain degree of transglycosylation activity, which means that they are capable of transferring the released oligosaccharide residue to a suitable acceptor generating new glycosidic linkages and forming specific COS [48,49].

Several factors can influence the outcome of a polysaccharide degradation reaction. Considering COS preparation, both the selection of enzyme and the choice of substrate exert a significant influence on the obtained products.

\section{Types of Chitooligosaccharides}

As previously mentioned, three types of COS can be prepared (Figure 1). In the following paragraphs, we will give some guidelines to direct the synthesis towards a specific family of compounds. 


\subsection{Fully Deacetylated Chitooligosaccharides (fdCOS)}

The preparation of $f d \mathrm{COS}$ can be carried out employing chitosanases [50] or some commercial preparations [16], but it generally requires a highly deacetylated chitosan as a substrate or a chitin deacetylase [2]. In our laboratory, two approaches were studied to obtain $f d$ COS: (1) the use of unspecific enzymes [46,51]; (2) the extraction of a chitosanolytic activity from the preparation of Bacillus thuringiensis used as a pesticide [20].

In the first case, several commercial enzyme cocktails were screened for chitosanolytic activity. Among the positives found, the proteolytic preparation Neutrase $0.8 \mathrm{~L}$ from B. amyloliquefaciens was selected because our goal was to obtain fully deacetylated products, and some proteases had demonstrated the ability to hydrolyze $\mathrm{N}$-acetyl residues in chitosan [52,53]. A highly deacetylated (DD > 90\%) chitosan (CHIT600) was chosen to favor the formation of $f d \mathrm{COS}$. After $24 \mathrm{~h}$ of reaction, the products were characterized by high-performance anion-exchange chromatography with pulsed amperometric detection (HPAEC-PAD) and matrix-assisted laser desorption/ionization with time-of-flight detection (MALDI-TOF) mass spectrometry. The main components were identified as glucosamine, chitobiose, chitotriose, chitotetraose and chitopentaose, and the deacetylation degree of the reaction mixtures was always between 95 and 100\% [46].

The second approach to obtain $f d \mathrm{COS}$ was the use of an enzyme extract obtained from commercial preparations of B. thuringiensis [20]. This preparation was assayed with different chitosans, and we observed that the higher reaction rates were obtained with, the more deacetylated chitosan (CHIT600), suggesting a higher specificity for deacetylated substrates (chitosanase activity). After $72 \mathrm{~h}$, the main reaction product was chitotetraose, with significant amounts of chitobiose, chitotriose and chitopentaose (Figure 3). The yield of identified deacetylated chitooligosaccharides was nearly $97 \%$.

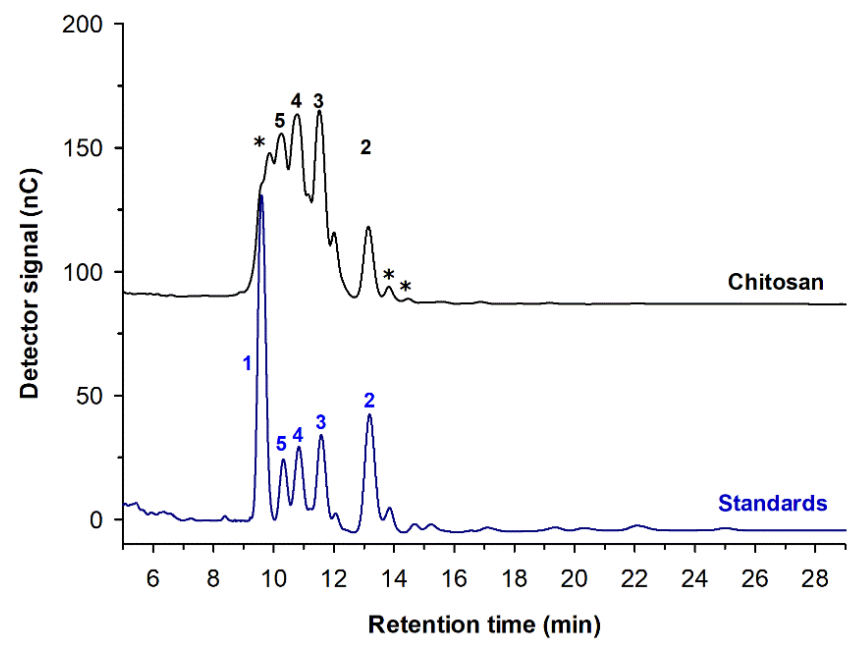

Figure 3. High-performance anion-exchange chromatography with pulsed amperometric detection (HPAEC-PAD) analysis of the COS synthesized by extracts from B. thuringiensis (var. aizawai) using chitosan CHIT600 (degree of deacetylation (DD) > 90\%) as substrate. Reaction conditions: 1\% ( $w / v$ ) chitosan, $50 \mathrm{mM}$ sodium acetate buffer ( $\mathrm{pH} 5.0), 60^{\circ} \mathrm{C}, 0.05 \mathrm{U} / \mathrm{mL}, 24 \mathrm{~h}$. Peaks: (1) GlcN; (2) $(\mathrm{GlcN})_{2}$; (3) $\left.(\mathrm{GlcN})_{3} ;(4)(\mathrm{GlcN})_{4} ;(5)(\mathrm{GlcN})_{5} ;{ }^{*}\right)$ unknown $f d \mathrm{COS}$ and $p a \mathrm{COS}$. A chromatogram of standards from GlcN to $(\mathrm{GlcN})_{5}$ is depicted below in blue. Adapted with permission from [20].

\subsection{Fully Acetylated Chitooligosaccharides (faCOS)}

The production of $f a C O S$ is usually performed with chitin as substrate, but due to chitin crystallinity and insolubility in aqueous media, pretreatment is necessary. Generally, chitin flakes are treated with strong acids and transformed into colloidal or swollen chitin [18]. In addition, chitinases or lysozyme are normally employed for chitin depolymerization $[54,55]$.

Our group studied the preparation of fully acetylated COS employing colloidal chitin and chitinase Chit42, a recombinant enzyme from Trichoderma harzianum [39] that belongs 
to the GH18 family. The hydrolysis of colloidal chitin with chitinase Chit42 for $24 \mathrm{~h}$ mainly yielded $\mathrm{N}$-acetyl-chitobiose, $\mathrm{N}$-acetyl-glucosamine and $\mathrm{N}$-acetyl-chitotriose. In addition, trace amounts of $\mathrm{N}$-acetyl-chitotetraose were found. Products were characterized by HPAEC-PAD and MALDI-TOF mass spectrometry (Figure 4), and the DD of the synthesized COS was lower than $5 \%$.
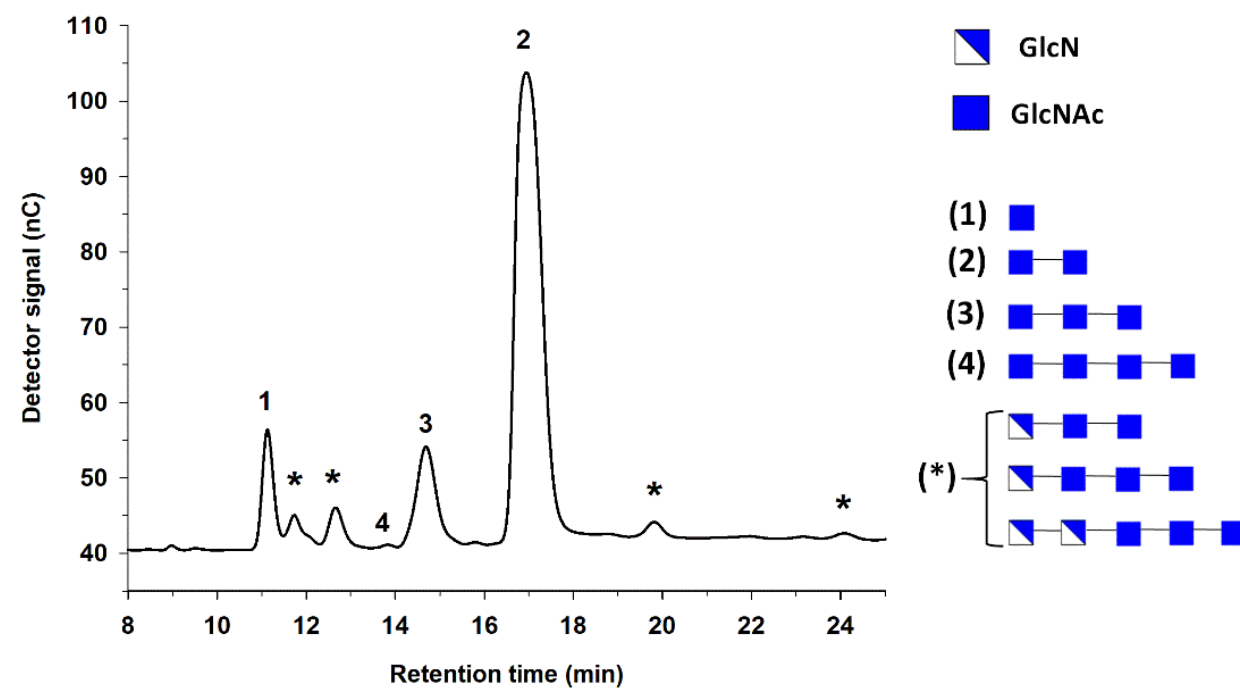

Figure 4. HPAEC-PAD chromatogram of the hydrolysis of colloidal chitin catalyzed by chitinase Chit42 from T. harzianum. Peaks: (1) GlcNAc; (2) (GlcNAc) $)_{2}$ (3) (GlcNAc) 3 ; (4) (GlcNAc) $)_{4} ;\left(^{*}\right)$ unknown. On the right, representation of the composition of reaction products predicted from matrixassisted laser desorption/ionization with time-of-flight detection (MALDI-TOF) mass spectrometry. Correspondence to HPAEC-PAD peaks is shown in parenthesis. Adapted with permission from [39].

\subsection{Partially Acetylated Chitooligosaccharides (paCOS)}

Several approaches can be followed for the preparation of partially acetylated COS. For example, chitosan degradation with a low degree of deacetylation (DD between 70 and $85 \%$ ) by chitosanases could probably yield a high amount of $p a C O S$. However, the combination of this type of chitosans with GH18 chitinases could be more effective because these enzymes require at least one GlcNAc moiety at the -1 position in the active site, thus assuring the presence in the synthesized products of a GlcNAc residue on their reducing ends.

The production of $p a \mathrm{COS}$ was studied by our group employing chitosan with a moderate DD (81\%) and chitinase Chit 42 from T. harzianum. The characterization of this kind of COS is quite complex due to the lack of commercial standards. HPAEC-PAD analysis revealed the presence of at least 11 unidentified peaks that probably corresponded to $p a \mathrm{COS}$, while MALDI-TOF analysis showed COS with DP $\leq 9$, mainly composed of GlcN residues and normally at least one moiety of GlcNAc. A related endo-chitinase from the same microorganism (Chit33) was expressed in Pichia pastoris and produced a mixture of fully and partially acetylated COS from different chitinolytic materials. In particular, the hydrolysis of chitosan yielded GlcN-(GlcNAc) ${ }_{2}$ as the major product [56].

In conclusion, it is possible to modulate the kind of synthesized COS by selecting the enzyme (chitinases, chitosanase) and/or the substrate (in particular, the degree of deacetylation). The different strategies are illustrated in Figure 5. 


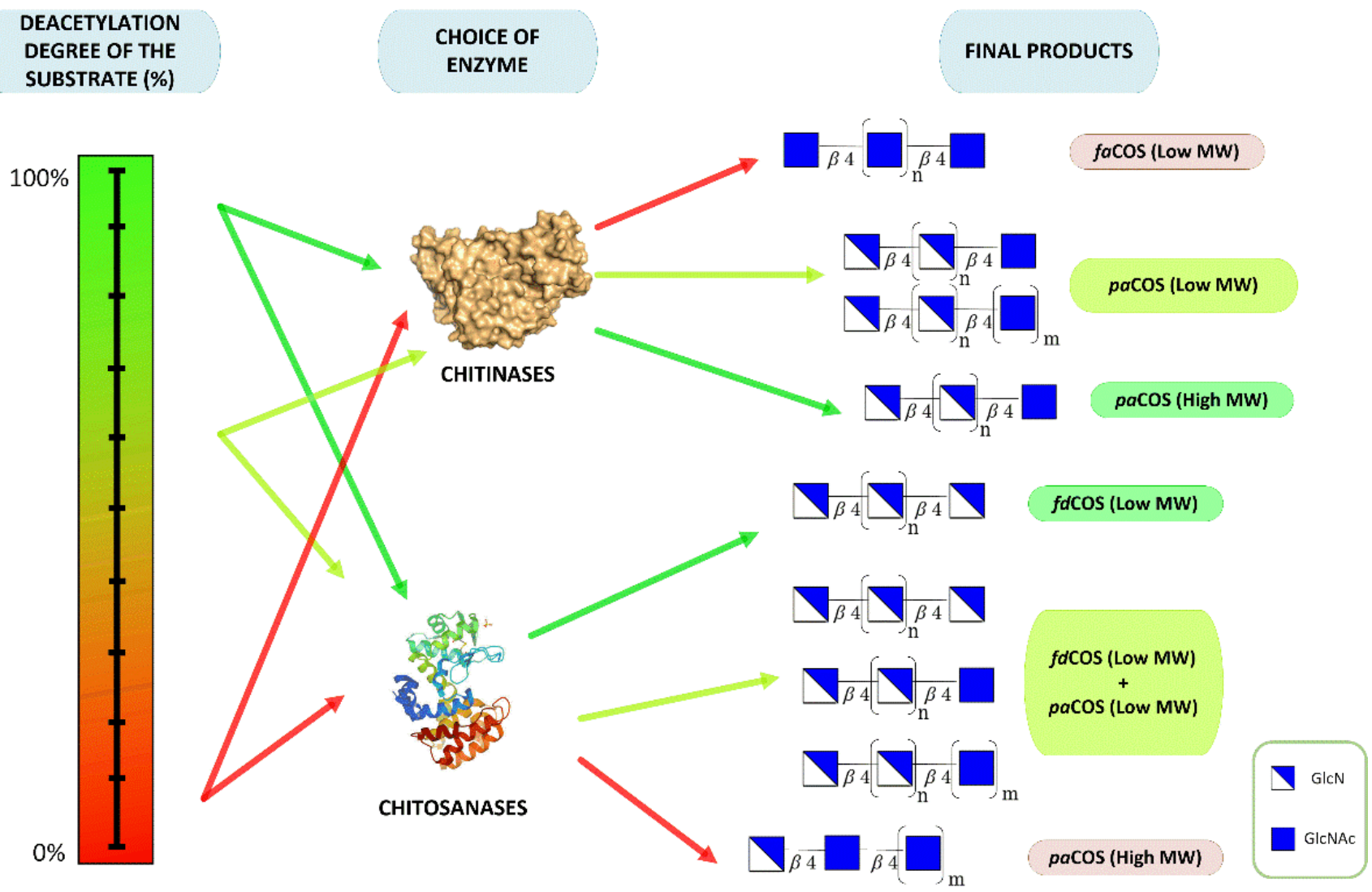

Figure 5. Strategies for the preparation of different types of chitooligosaccharides.

\section{Large-Scale Procedure for the Production of Chitooligosaccharides}

The scale-up of COS synthesis offers several difficulties derived from the low aqueous solubility of the substrates, the heterogeneity of the reaction mixtures and the presence of high concentrations of salts. Based on previous works performed in our laboratory at a small scale, the commercial proteolytic preparation Neutrase $0.8 \mathrm{~L}$ [46] and the chitinase Chit42 from T. harzianum [39] were selected to scale-up the synthesis of several COS mixtures. Chitosans of different sizes and DD (Table 1) were hydrolyzed with one or both enzymes acting synergically.

Table 1. Main properties of the chitosans employed in the scale-up of COS synthesis.

\begin{tabular}{ccc}
\hline Chitosan & Molecular Mass (kDa) $^{\mathbf{1}}$ & Deacetylation Degree (\%) $^{\mathbf{1}}$ \\
\hline CHIT2 & 56 & 79 \\
QS1 & 98 & 81 \\
CHIT600 & $600-100$ & $>90$ \\
\hline
\end{tabular}

${ }^{1}$ Data from the providers.

A common procedure was designed for the large-scale production of COS of different sizes and DD (Figure 6), which could illustrate the difficulties in the downstream processing of these mixtures. 


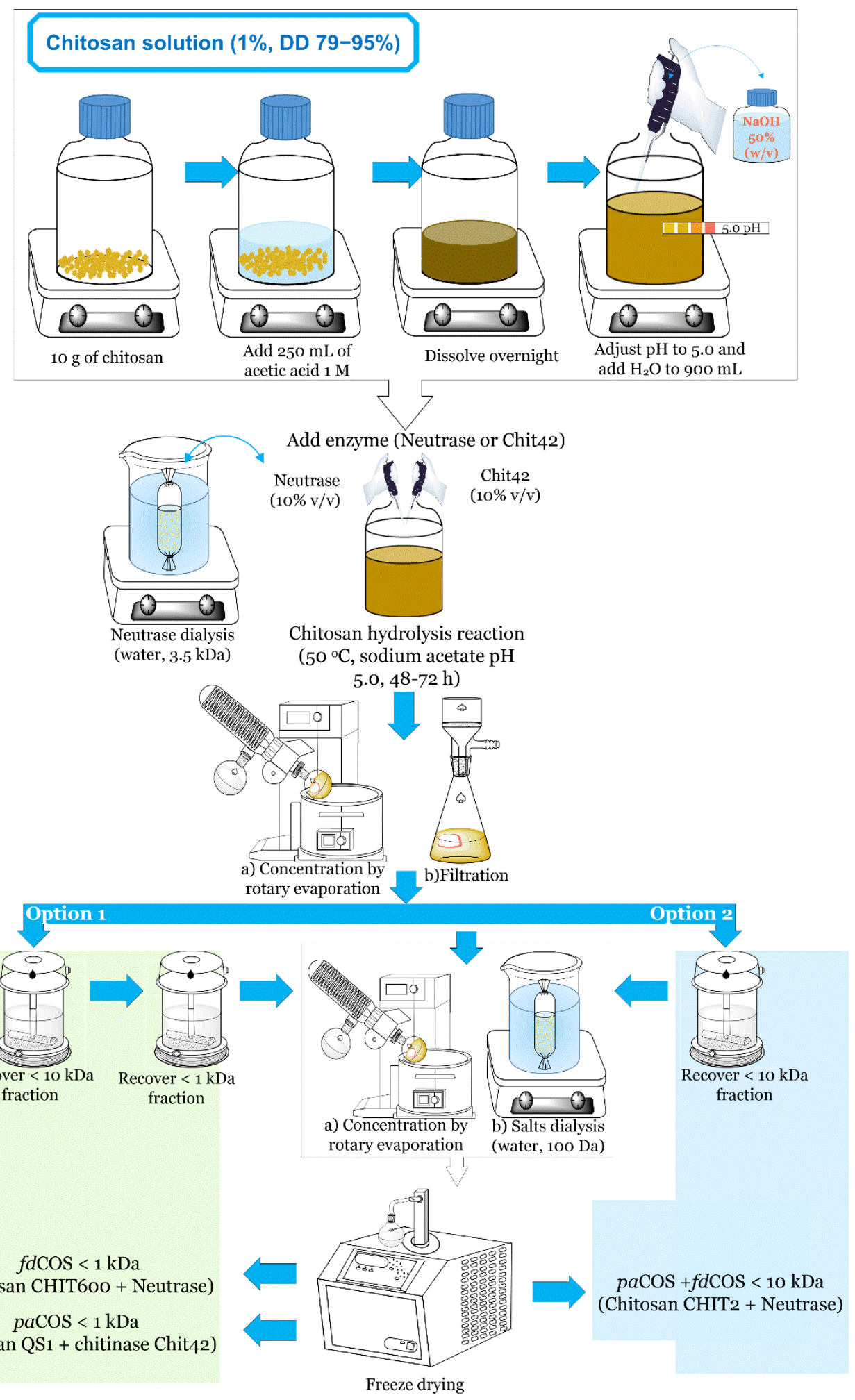

Figure 6. Strategies for the preparation of different types of chitooligosaccharides.

First, chitosan $(1 \%, w / v)$ was dissolved in sodium acetate buffer ( $\mathrm{pH} 5.0)$, and hydrolysis was carried out at $35-50{ }^{\circ} \mathrm{C}$ for $48-72 \mathrm{~h}$. In the case of commercial Neutrase $0.8 \mathrm{~L}$, the enzyme was previously dialyzed to remove low-molecular-weight components. Afterward, enzymes and the remaining chitosan were removed by ultrafiltration with a $10 \mathrm{kDa}$ membrane. Acetone or ethanol precipitation is also an alternative to separate water-insoluble components [57]. To obtain a fraction of COS with low molecular weight 
$(\mathrm{DP} \leq 6)$, ultrafiltration with a $1 \mathrm{kDa}$ membrane was applied to some mixtures (option 1). Size-exclusion chromatography, ion-exchange chromatography and tangential filtration are also alternatives to ultrafiltration to fractionate $\operatorname{COS}[58,59]$. In all cases, salts and small contaminants were eliminated by dialysis with 100 Da tubing, and COS fractions were freeze-dried.

This common methodology (with slight modifications) was employed for the depolymerization of chitosan. Depending on the characteristics of the chitosan (DD, PA, DP) and the enzyme used, different reaction outcomes were obtained (Figure 6). Consequently, we were able to prepare a mixture of majorly $f d \mathrm{COS}$ with $\mathrm{MW} \leq 1 \mathrm{kDa}$, a mixture mainly containing $p a C O S$ with $\mathrm{MW} \leq 1 \mathrm{kDa}$, and a mixture of $f d \mathrm{COS}$ and $p a \mathrm{COS}$ with $\mathrm{MW} \leq 10 \mathrm{kDa}$.

Enzyme immobilization is a powerful tool that can facilitate the scaling-up of many biocatalytic processes [60], including those involved in the production of bioactive oligosaccharides [61]. This technology makes enzyme recovery and the reuse of the biocatalysts easier, and it usually increases the operational stability of the enzymes [62]. In this context, we recently immobilized chitinase Chit42 from T. harzianum onto different carriers: (1) magnetic nanoparticles; (2) chitosan beads with glutaraldehyde or genipin linkers [63]. The immobilized biocatalysts showed improved operational stability and were applied to the synthesis of COS from colloidal chitin and several chitosans. We demonstrated that the biocatalysts were easy to handle and separate from the reaction mixture and thus could be reused.

We have also investigated the continuous production of COS in packed-bed reactors. For such purpose, we selected a chitosanolytic activity present in a commercial $\alpha$-amylase preparation (BAN), which was covalently immobilized onto glyoxal agarose beads [51]. The immobilization did not change the product profile but increased the enzyme thermostability. We developed a two-step process in which (1) chitosan was first hydrolyzed in a batch reactor to reduce the viscosity; (2) the pretreated chitosan was pumped through a packedbead reactor (PBR) with immobilized enzyme, thus avoiding clogging of the column.

\section{Bioactive Properties of COS}

COS are natural antioxidants [9]. Several studies in vivo have proved that COS can inhibit reactive oxygen species (ROS) and, in consequence, different pathways of the cell damage caused by oxidative stress $[64,65]$. The molecular mechanism that explains the antioxidant activities of the different COS families has not been completely elucidated [3], although it was postulated that free amino groups of chitosan could interact with free radicals giving rise to stable macroradicals. COS probably display their biological actions by modulating different targets. Interestingly, COS with a molecular mass lower than $5 \mathrm{kDa}$ have displayed the highest antioxidant activities [66].

COS display a myriad of bioactivities, including neuroprotective [67], anti-inflammatory [12], antihypertensive [68], antimicrobial [69], antiviral [70], antiangiogenic [71], antitumor [72] and prebiotic $[19,73]$.

The reported results on the bioactivity of COS reflect clear discrepancies, which can be explained by the heterogeneity of the synthesized oligosaccharide samples and the use of different bioassays. In many cases, the chemical composition and molecular weight of COS are not fully determined before the assay. To obtain a reproducible product for bioassays, the raw materials and the extent to which the substrate hydrolysis is allowed to proceed should be carefully controlled.

COS have shown antimicrobial activity against bacteria, filamentous fungi and yeasts $[15,74]$. The advantage of COS vs. chitosan is that the former can be used at $\mathrm{pH}>6.5$, whereas the polymer is insoluble in water. In this context, COS have been proposed as polycationic biocides [66]. The mechanism by which COS inhibit microbial growth could be related to the interaction of free $\mathrm{NH}_{2}$ groups of glucosamine moieties with carboxylic residues present in the outer cell membranes of microorganisms [33,75]. On the other hand, Sanchez et al. reported that partially acetylated COS ( $p a C O S)$ exhibit better antibacterial 
activity towards Listeria monocytogenes and Escherichia coli than fully deacetylated COS ( $f d \mathrm{COS})$, suggesting the essential role of acetamide moieties in the antimicrobial properties of these compounds [76].

COS is also able to induce the resistance of plants and animals towards various viral infections $[70,77]$. Although the mechanism is still unclear, the reduction of infectivity could be associated with a minor absorption of virus onto the cell membrane.

The molecular features that determine the anti-tumor activity of COS have not been elucidated yet. However, Huang et al. postulated that electrostatic interactions between tumor cells and polycationic chitosan oligosaccharides could alter the membrane permeability of such cells [78]. COS possess great potential as immunostimulatory agents in novel anticancer therapies [79]. The fermentation of COS in vitro and its effect on human fecal microbial community structure and metabolites have been recently reported [80]. In other contexts, COS and their derivatives can be employed in drug delivery of anticancer drugs [81].

\section{Effect of COS Composition on Anti-Inflammatory Properties}

The role that inflammation plays in the course of various pathologies, such as cancer and autoimmune diseases, is well reported [82]. The anti-inflammatory activity of three COS mixtures, enriched in $f d \mathrm{COS}, p a \mathrm{COS}$ and $f a C O S$, respectively, was assayed by our group to assess the influence of COS nature on the activity [83]. This was investigated by measuring the decrease in the levels of TNF- $\alpha$ (tumor necrosis factor) in murine macrophages (RAW264.7) after stimulation with a mixture of lipopolysaccharides (LPS). The amount of TNF- $\alpha$ was measured at different times upon incubation with $10 \mathrm{ng} /$ well of LPS. TNF- $\alpha$ reached its highest concentration after $6 \mathrm{~h}$ post-stimulation with LPS (data not shown).

The secretion of TNF- $\alpha$ decreased during the first $6 \mathrm{~h}$ in macrophages treated with the three COS mixtures in comparison with macrophages stimulated with LPS only (Figure 7). These results confirmed the inhibitory effect of COS against inflammation. Figure 7 shows the results using $250 \mathrm{ng}$ of COS per well, which was the best of the assayed concentrations.

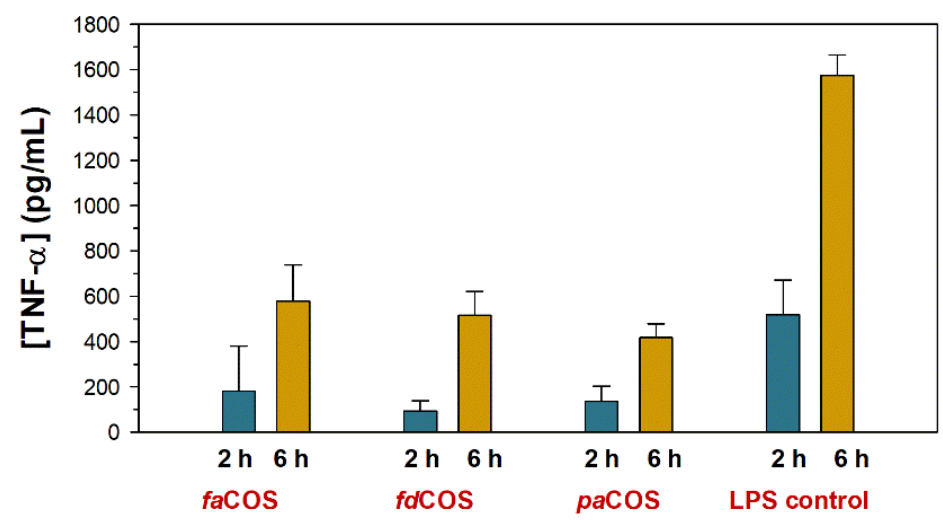

Figure 7. Effect of fully deacetylated ( $f d C O S)$, fully acetylated ( $f a C O S$ ) and partially acetylated ( $p a \mathrm{COS}$ ) (at $250 \mathrm{ng}$ per well) on tumor necrosis factor (TNF- $\alpha$ ) concentration from cells stimulated with lipopolysaccharides (10 ng/well). The pictures show the amount of TNF- $\alpha$ at 2 and $6 \mathrm{~h}$ after stimulation. Adapted with permission from [83].

According to Yoon et al., the attenuation of secretion of TNF- $\alpha$ induced by LPS after incubation with COS was regulated at the transcription level [84]. Previous studies on the effect of COS composition on their anti-inflammatory activity focused mostly on the molecular size $[85,86]$ rather than the degree of deacetylation. Regarding the effect of DD on anti-inflammatory behavior, Lee et al. demonstrated that highly deacetylated COS showed higher anti-inflammatory activity than COS with an average of $50 \% \mathrm{~N}$-deacetylation (representative of paCOS) [87]. In general, low MW and high DD seems to increase the anti-inflammatory properties [86]. 


\section{Conclusions}

COS have a wide variety of biological activities, which explain the potential of these molecules in the food, pharmaceutical, cosmetic or agricultural industries. However, these properties are influenced by the chemical composition of the oligosaccharides, in particular their size, deacetylation degree and pattern of acetylation. Therefore, the selective synthesis of well-characterized COS mixtures is of great value for a deeper understanding of their bioactivity and thus their future applications. The appropriate selection of the chitin/chitosan feedstock and the enzyme source, in particular its chitinolytic or chitosanolytic profile, is essential to direct the synthesis towards a particular type of COS.

Author Contributions: F.J.P. and M.F.-L. conceived and designed the experiments; N.M., P.K. and P.S.-M. carried out most of the experiments; N.M. and F.J.P. wrote the paper, which was improved by the rest of the authors. F.J.P., M.F.-L. and A.O.B. were involved in funding acquisition. All authors have read and agreed to the published version of the manuscript.

Funding: This work was supported by grants from the EU EMFF-Blue Economy-2018 (FISH4FISH863697 project), the Spanish Ministry of Economy and Competitiveness (Grants BIO2016-76601C3-1,2-R), the Spanish Ministry of Science and Innovation (Grants PID2019-105838RB-C31/C32), Fundación Ramón Areces (XIX Call of Research Grants in Life and Material Sciences) and by an institutional grant from Fundación Ramón Areces to the Centro de Biología Molecular.

Acknowledgments: We thank Ramiro Martinez (Novozymes A/S, Spain) for supplying commercial enzymes and for relevant suggestions. We thank Laura Córdoba and Miguel Angel Llamas (Diomune S.L.) for their support in the analysis of anti-inflammatory properties.

Conflicts of Interest: The authors declare no conflict of interest.

\section{References}

1. Hamed, I.; Özogul, F.; Regenstein, J.M. Industrial applications of crustacean by-products (chitin, chitosan, and chitooligosaccharides): A review. Trends Food Sci. Technol. 2016, 48, 40-50. [CrossRef]

2. Hamer, S.N.; Cord-Landwehr, S.; Biarnés, X.; Planas, A.; Waegeman, H.; Moerschbacher, B.M.; Kolkenbrock, S. Enzymatic production of defined chitosan oligomers with a specific pattern of acetylation using a combination of chitin oligosaccharide deacetylases. Sci. Rep. 2015, 5, 8716. [CrossRef]

3. Zhou, J.; Wen, B.; Xie, H.; Zhang, C.; Bai, Y.; Cao, H.; Che, Q.; Guo, J.; Su, Z. Advances in the preparation and assessment of the biological activities of chitosan oligosaccharides with different structural characteristics. Food Funct. 2021, 12, 926-951. [CrossRef] [PubMed]

4. Grifoll-Romero, L.; Pascual, S.; Aragunde, H.; Biarnés, X.; Planas, A. Chitin deacetylases: Structures, specificities, and biotech applications. Polymers 2018, 10, 352. [CrossRef] [PubMed]

5. Xia, W.; Liu, P.; Zhang, J.; Chen, J. Biological activities of chitosan and chitooligosaccharides. Food Hydrocoll. 2011, 25, 170-179. [CrossRef]

6. Park, B.K.; Kim, M.M. Applications of chitin and its derivatives in biological medicine. Int. J. Mol. Sci. 2010, 11, 5152-5164. [CrossRef] [PubMed]

7. Yang, Y.; Yu, B. Recent advances in the synthesis of chitooligosaccharides and congeners. Tetrahedron 2014, 70, 1023-1046. [CrossRef]

8. Sun, H.; Gao, L.; Xue, C.; Mao, X. Marine-polysaccharide degrading enzymes: Status and prospects. Compr. Rev. Food Sci. Food Saf. 2020, 19, 2767-2796. [CrossRef]

9. Chen, A.S.; Taguchi, T.; Sakai, K.; Kikuchi, K.; Wang, M.W.; Miwa, I. Antioxidant activities of chitobiose and chitotriose. Biol. Pharm. Bull. 2003, 26, 1326-1330. [CrossRef] [PubMed]

10. Kumar, M.; Brar, A.; Vivekanand, V.; Pareek, N. Bioconversion of chitin to bioactive chitooligosaccharides: Amelioration and coastal pollution reduction by microbial resources. Mar. Biotechnol. 2018, 20, 269-281. [CrossRef]

11. Zhao, M.; Gu, L.; Li, Y.; Chen, S.; You, J.; Fan, L.; Wang, Y.; Zhao, L. Chitooligosaccharides display anti-tumor effects against human cervical cancer cells via the apoptotic and autophagic pathways. Carbohydr. Polym. 2019, 224, 115171. [CrossRef] [PubMed]

12. Sánchez, Á.; Mengíbar, M.; Fernández, M.; Alemany, S.; Heras, A.; Acosta, N. Influence of preparation methods of chitooligosaccharides on their physicochemical properties and their anti-inflammatory effects in mice and in RAW264.7 macrophages. Mar. Drugs 2018, 16, 430. [CrossRef]

13. Marmouzi, I.; Ezzat, S.M.; Salama, M.M.; Merghany, R.M.; Attar, A.M.; El-Desoky, A.M.; Mohamed, S.O. Recent Updates in pharmacological properties of chitooligosaccharides. BioMed. Res. Int. 2019, 2019, 4568039. [CrossRef]

14. Yang, Y.; Xing, R.; Liu, S.; Qin, Y.; Li, K.; Yu, H.; Li, P. Immunostimulatory Effects of Chitooligosaccharides on RAW 264.7 Mouse Macrophages via Regulation of the MAPK and PI3K/Akt Signaling Pathways. Mar. Drugs 2019, 17, 36. [CrossRef] 
15. Guan, G.; Azad, M.A.K.; Lin, Y.; Kim, S.W.; Tian, Y.; Liu, G.; Wang, H. Biological effects and applications of chitosan and chito-oligosaccharides. Front. Physiol. 2019, 10, 516. [CrossRef]

16. Xia, W.; Liu, P.; Liu, J. Advance in chitosan hydrolysis by non-specific cellulases. Bioresour. Technol. 2008, 99, 6751-6762. [CrossRef]

17. Aktuganov, G.E.; Melentiev, A.I.; Varlamov, V.P. Biotechnological Aspects of the Enzymatic Preparation of Bioactive Chitooligosaccharides. Appl. Biochem. Microbiol. 2019, 55, 323-343. [CrossRef]

18. Moon, C.; Seo, D.J.; Song, Y.S.; Hong, S.H.; Choi, S.H.; Jung, W.J. Antifungal activity and patterns of N-acetyl-chitooligosaccharide degradation via chitinase produced from Serratia marcescens PRNK-1. Microb. Pathog. 2017, 113, 218-224. [CrossRef] [PubMed]

19. Ismail, S.A.; El-Sayed, H.S.; Fayed, B. Production of prebiotic chitooligosaccharide and its nano/microencapsulation for the production of functional yoghurt. Carbohydr. Polym. 2020, 234, 115941. [CrossRef] [PubMed]

20. Santos-Moriano, P.; Kidibule, P.E.; Alleyne, E.; Ballesteros, A.O.; Heras, A.; Fernandez-Lobato, M.; Plou, F.J. Efficient conversion of chitosan into chitooligosaccharides by a chitosanolytic activity from Bacillus thuringiensis. Process Biochem. 2018, 73, 102-108. [CrossRef]

21. Baxter, S.; Zivanovic, S.; Weiss, J. Molecular weight and degree of acetylation of high-intensity ultrasonicated chitosan. Food Hydrocoll. 2005, 19, 821-830. [CrossRef]

22. Wu, Y.; Huang, Y.; Zhou, Y.; Ren, X.e.; Yang, F. Degradation of chitosan by swirling cavitation. Innov. Food Sci. Emerg. Technol. 2014, 23, 188-193. [CrossRef]

23. Zainol, I.; Akil, H.M.; Mastor, A. Effect of $\gamma$-irradiation on the physical and mechanical properties of chitosan powder. Mater. Sci. Eng. C 2009, 29, 292-297. [CrossRef]

24. Trombotto, S.; Ladavière, C.; Delolme, F.; Domard, A. Chemical preparation and structural characterization of a homogeneous series of chitin/chitosan oligomers. Biomacromolecules 2008, 9, 1731-1738. [CrossRef] [PubMed]

25. Xia, Z.; Wu, S.; Chen, J. Preparation of water soluble chitosan by hydrolysis using hydrogen peroxide. Int. J. Biol. Macromol. 2013, 59, 242-245. [CrossRef]

26. Je, J.Y.; Kim, S.K. Chitooligosaccharides as potential nutraceuticals: Production and bioactivities. Adv. Food Nutr. Res. 2012, 65, 321-336.

27. Sinha, S.; Chand, S.; Tripathi, P. Recent progress in chitosanase production of monomer-free chitooligosaccharides: Bioprocess strategies and future applications. Appl. Biochem. Biotechnol. 2016, 180, 883-899. [CrossRef]

28. Sheldon, R.A.; Woodley, J.M. Role of Biocatalysis in sustainable chemistry. Chem. Rev. 2018, 118, 801-838. [CrossRef]

29. Oyeleye, A.; Normi, Y.M. Chitinase: Diversity, limitations, and trends in Engineering for suitable applications. Biosci. Rep. 2018, 38, BSR2018032300. [CrossRef]

30. Singh, R.V.; Sambyal, K.; Negi, A.; Sonwani, S.; Mahajan, R. Chitinases production: A robust enzyme and its industrial applications. Biocatal. Biotransform. 2021, 39, 161-189. [CrossRef]

31. Thadathil, N.; Velappan, S.P. Recent developments in chitosanase research and its biotechnological applications: A review. Food Chem. 2014, 150, 392-399. [CrossRef] [PubMed]

32. Li, H.; Fei, Z.; Gong, J.; Yang, T.; Xu, Z.; Shi, J. Screening and characterization of a highly active chitosanase based on metagenomic technology. J. Mol. Catal. B Enzym. 2015, 111, 29-35. [CrossRef]

33. Kittur, F.S.; Vishu Kumar, A.B.; Varadaraj, M.C.; Tharanathan, R.N. Chitooligosaccharides—Preparation with the aid of pectinase isozyme from Aspergillus niger and their antibacterial activity. Carbohydr. Res. 2005, 340, 1239-1245. [CrossRef]

34. Montilla, A.; Ruiz-Matute, A.I.; Corzo, N.; Giacomini, C.; Irazoqui, G. Enzymatic generation of chitooligosaccharides from chitosan using soluble and immobilized glycosyltransferase (Branchzyme). J. Agric. Food Chem. 2013, 61, 10360-10367. [CrossRef] [PubMed]

35. Cantarel, B.L.; Coutinho, P.M.; Rancurel, C.; Bernard, T.; Lombard, V.; Henrissat, B. The Carbohydrate-Active EnZymes database (CAZy): An expert resource for Glycogenomics. Nucleic Acids Res. 2009, 37, D233-D238. [CrossRef] [PubMed]

36. Sunny, N.E.; Rajesh Kumar, S.; Venkat Kumar, S. A review on Chitinase synthesis from varied sources and its applications towards environment. Res. J. Pharm. Technol. 2018, 11, 4200-4208. [CrossRef]

37. Liu, S.; Shao, S.; Li, L.; Cheng, Z.; Tian, L.; Gao, P.; Wang, L. Substrate-binding specificity of chitinase and chitosanase as revealed by active-site architecture analysis. Carbohydr. Res. 2015, 418, 50-56. [CrossRef]

38. Huang, Q.S.; Xie, X.L.; Liang, G.; Gong, F.; Wang, Y.; Wei, X.Q.; Wang, Q.; Ji, Z.L.; Chen, Q.X. The GH18 family of chitinases: Their domain architectures, functions and evolutions. Glycobiology 2012, 22, 23-34. [CrossRef] [PubMed]

39. Kidibule, P.E.; Santos-Moriano, P.; Jiménez-Ortega, E.; Ramírez-Escudero, M.; Limón, M.C.; Remacha, M.; Plou, F.J.; Sanz-Aparicio, J.; Fernández-Lobato, M. Use of chitin and chitosan to produce new chitooligosaccharides by chitinase Chit42: Enzymatic activity and structural basis of protein specificity. Microb. Cell Fact. 2018, 17, 47. [CrossRef]

40. Lienemann, M.; Boer, H.; Paananen, A.; Cottaz, S.; Koivula, A. Toward understanding of carbohydrate binding and substrate specificity of a glycosyl hydrolase 18 family (GH-18) chitinase from Trichoderma harzianum. Glycobiology 2009, 19, 1116-1126. [CrossRef]

41. Hoell, I.A.; Vaaje-Kolstad, G.; Eijsink, V.G.H. Structure and function of enzymes acting on chitin and chitosan. Biotechnol. Genet. Eng. Rev. 2010, 27, 331-366. [CrossRef]

42. Aktuganov, G.E.; Melent'ev, A.I. Specific features of chitosan depolymerization by chitinases, chitosanases, and nonspecific enzymes in the production of bioactive chitooligosaccharides. Appl. Biochem. Microbiol. 2017, 53, 611-627. [CrossRef] 
43. Weikert, T.; Niehues, A.; Cord-Landwehr, S.; Hellmann, M.J.; Moerschbacher, B.M. Reassessment of chitosanase substrate specificities and classification. Nat. Commun. 2017, 8, 1698. [CrossRef]

44. Olicón-Hernández, D.R.; Vázquez-Landaverde, P.A.; Cruz-Camarillo, R.; Rojas-Avelizapa, L.I. Comparison of chitooligosaccharide production from three different colloidal chitosans using the endochitonsanolytic system of Bacillus thuringiensis. Prep. Biochem. Biotechnol. 2017, 47, 116-122. [CrossRef]

45. Pantaleone, D.; Yalpani, M.; Scollar, M. Unusual susceptibility of chitosan to enzymic hydrolysis. Carbohydr. Res. 1992, 237, 325-332. [CrossRef]

46. Santos-Moriano, P.; Fernandez-Arrojo, L.; Mengibar, M.; Belmonte-Reche, E.; Peñalver, P.; Acosta, F.N.; Ballesteros, A.O.; Morales, J.C.; Kidibule, P.; Fernandez-Lobato, M.; et al. Enzymatic production of fully deacetylated chitooligosaccharides and their neuroprotective and anti-inflammatory properties. Biocatal. Biotransform. 2018, 36, 57-67. [CrossRef]

47. Arnold, N.D.; Brück, W.M.; Garbe, D.; Brück, T.B. Enzymatic modification of native chitin and conversion to specialty chemical products. Mar. Drugs 2020, 18, 93. [CrossRef]

48. Mallakuntla, M.K.; Vaikuntapu, P.R.; Bhuvanachandra, B.; Podile, A.R. Selection and mutational analyses of the substrate interacting residues of a chitinase from Enterobacter cloacae subsp. cloacae (EcChi2) to improve transglycosylation. Int. J. Biol. Macromol. 2020, 165, 2432-2441. [CrossRef] [PubMed]

49. Tanabe, T.; Morinaga, K.; Fukamizo, T.; Mitsutomi, M. Novel chitosanase from Streptomyces griseus HUT 6037 with transglycosylation activity. Biosci. Biotechnol. Biochem. 2003, 67, 354-364. [CrossRef] [PubMed]

50. Nidheesh, T.; Pal, G.K.; Suresh, P.V. Chitooligomers preparation by chitosanase produced under solid state fermentation using shrimp by-products as substrate. Carbohydr. Polym. 2015, 121, 1-9. [CrossRef]

51. Santos-Moriano, P.; Woodley, J.M.; Plou, F.J. Continuous production of chitooligosaccharides by an immobilized enzyme in a dual-reactor system. J. Mol. Catal. B Enzym. 2016, 133, 211-217. [CrossRef]

52. Kumar, A.B.V.; Tharanathan, R.N. A comparative study on depolymerization of chitosan by proteolytic enzymes. Carbohydr. Polym. 2004, 58, 275-283.

53. Pan, A.D.; Zeng, H.-Y.; Foua, G.B.; Alain, C.; Li, Y.-Q. Enzymolysis of chitosan by papain and its kinetics. Carbohydr. Polym. 2016, 135, 199-206. [CrossRef]

54. Mengíbar, M.; Mateos-Aparicio, I.; Miralles, B.; Heras, A. Influence of the physico-chemical characteristics of chitooligosaccharides (COS) on antioxidant activity. Carbohydr. Polym. 2013, 97, 776-782. [CrossRef] [PubMed]

55. Ortiz-Rodríguez, T.; De La Fuente-Salcido, N.; Bideshi, D.K.; Salcedo-Hernández, R.; Barboza-Corona, J.E. Generation of chitinderived oligosaccharides toxic to pathogenic bacteria using ChiA74, an endochitinase native to Bacillus thuringiensis. Lett. Appl. Microbiol. 2010, 51, 184-190. [CrossRef] [PubMed]

56. Kidibule, P.E.; Santos-Moriano, P.; Plou, F.J.; Fernández-Lobato, M. Endo-chitinase Chit33 specificity on different chitinolytic materials allows the production of unexplored chitooligosaccharides with antioxidant activity. Biotechnol. Rep. 2020, 27, e00500. [CrossRef] [PubMed]

57. Kazami, N.; Sakaguchi, M.; Mizutani, D.; Masuda, T.; Wakita, S.; Oyama, F.; Kawakita, M.; Sugahara, Y. A simple procedure for preparing chitin oligomers through acetone precipitation after hydrolysis in concentrated hydrochloric acid. Carbohydr. Polym. 2015, 132, 304-310. [CrossRef] [PubMed]

58. Hao, W.; Li, K.; Li, P. Review: Advances in preparation of chitooligosaccharides with heterogeneous sequences and their bioactivity. Carbohydr. Polym. 2021, 252, 117206. [CrossRef] [PubMed]

59. Li, K.; Xing, R.; Liu, S.; Li, P. Advances in preparation, analysis and biological activities of single chitooligosaccharides. Carbohydr. Polym. 2016, 139, 178-190. [CrossRef]

60. Torres-Salas, P.; Del Monte-Martinez, A.; Cutiño-Avila, B.; Rodriguez-Colinas, B.; Alcalde, M.; Ballesteros, A.O.; Plou, F.J. Immobilized biocatalysts: Novel approaches and tools for binding enzymes to supports. Adv. Mater. 2011, 23, 5275-5282. [CrossRef]

61. Míguez, N.; Gimeno-Pérez, M.; Fernández-Polo, D.; Cervantes, F.; Ballesteros, A.; Fernández-Lobato, M.; Ribeiro, M.; Plou, F. Immobilization of the $\beta$-fructofuranosidase from Xanthophyllomyces dendrorhous by entrapment in polyvinyl alcohol and its application to neo-fructooligosaccharides production. Catalysts 2018, 8, 201. [CrossRef]

62. Sheldon, R.A. Enzyme immobilization: The quest for optimum performance. Adv. Synth. Catal. 2007, 349, 1289-1307. [CrossRef]

63. Kidibule, P.E.; Costa, J.; Atrei, A.; Plou, F.J.; Fernandez-Lobato, M.; Pogni, R. Production and characterization of chitooligosaccharides by the fungal chitinase Chit42 immobilized on magnetic nanoparticles and chitosan beads: Selectivity, specificity and improved operational utility. RSC Adv. 2021, 11, 5529-5536. [CrossRef]

64. Oh, S.-H.; Vo, T.-S.; Ngo, D.-H.; Kim, S.-Y.; Ngo, D.-N.; Kim, S.-K. Prevention of H2O2-induced oxidative stress in murine microglial BV-2 cells by chitin-oligomers. Process Biochem. 2016, 51, 2170-2175. [CrossRef]

65. Luo, Z.; Dong, X.; Ke, Q.; Duan, Q.; Shen, L. Chitooligosaccharides inhibit ethanol-induced oxidative stress via activation of Nrf2 and reduction of MAPK phosphorylation. Oncol. Rep. 2014, 32, 2215-2222. [CrossRef] [PubMed]

66. Kaczmarek, M.B.; Struszczyk-Swita, K.; Li, X.; Szczęsna-Antczak, M.; Daroch, M. Enzymatic modifications of chitin, chitosan, and chitooligosaccharides. Front. Bioeng. Biotechnol. 2019, 7, 243. [CrossRef]

67. Jiang, M.; Guo, Z.; Wang, C.; Yang, Y.; Liang, X.; Ding, F. Neural activity analysis of pure chito-oligomer components separated from a mixture of chitooligosaccharides. Neurosci. Lett. 2014, 581, 32-36. [CrossRef] [PubMed] 
68. Huang, R.; Mendis, E.; Kim, S.K. Improvement of ACE inhibitory activity of chitooligosaccharides (COS) by carboxyl modification. Bioorganic Med. Chem. 2005, 13, 3649-3655. [CrossRef] [PubMed]

69. Wu, S.-J.; Pan, S.-K.; Wang, H.-B.; Wu, J.-H. Preparation of chitooligosaccharides from cicada slough and their antibacterial activity. Int. J. Biol. Macromol. 2013, 62, 348-351. [CrossRef]

70. Artan, M.; Karadeniz, F.; Karagozlu, M.Z.; Kim, M.M.; Kim, S.K. Anti-HIV-1 activity of low molecular weight sulfated chitooligosaccharides. Carbohydr. Res. 2010, 345, 656-662. [CrossRef] [PubMed]

71. Wu, H.; Aam, B.B.; Wang, W.; Norberg, A.L.; Sørlie, M.; Eijsink, V.G.H.; Du, Y. Inhibition of angiogenesis by chitooligosaccharides with specific degrees of acetylation and polymerization. Carbohydr. Polym. 2012, 89, 511-518. [CrossRef] [PubMed]

72. Kim, E.K.; Je, J.Y.; Lee, S.J.; Kim, Y.S.; Hwang, J.W.; Sung, S.H.; Moon, S.H.; Jeon, B.T.; Kim, S.K.; Jeon, Y.J.; et al. Chitooligosaccharides induce apoptosis in human myeloid leukemia HL-60 cells. Bioorganic Med. Chem. Lett. 2012, 22, 6136-6138. [CrossRef] [PubMed]

73. Fernandes, J.C.; Eaton, P.; Franco, I.; Ramos, Ó.S.; Sousa, S.; Nascimento, H.; Gomes, A.; Santos-Silva, A.; Xavier Malcata, F.; Pintado, M.E. Evaluation of chitoligosaccharides effect upon probiotic bacteria. Int. J. Biol. Macromol. 2012, 50, 148-152. [CrossRef] [PubMed]

74. Simunek, J.; Koppova, I.; Filip, L.; Tishchenko, G.; Belzecki, G. The antimicrobial action of low-molar-mass chitosan, chitosan derivatives and chitooligosaccharides on bifidobacteria. Folia Microbiol. 2010, 55, 379-382. [CrossRef] [PubMed]

75. Vishu Kumar, A.B.; Varadaraj, M.C.; Gowda, L.R.; Tharanathan, R.N. Low molecular weight chitosans-Preparation with the aid of pronase, characterization and their bactericidal activity towards Bacillus cereus and Escherichia coli. Biochim. Biophys. Acta (BBA)—Gen. Subj. 2007, 1770, 495-505. [CrossRef]

76. Sánchez, Á.; Mengíbar, M.; Rivera-Rodríguez, G.; Moerchbacher, B.; Acosta, N.; Heras, A. The effect of preparation processes on the physicochemical characteristics and antibacterial activity of chitooligosaccharides. Carbohydr. Polym. 2017, 157, $251-257$. [CrossRef]

77. Naveed, M.; Phil, L.; Sohail, M.; Hasnat, M.; Baig, M.M.F.A.; Ihsan, A.U.; Shumzaid, M.; Kakar, M.U.; Mehmood Khan, T.; Akabar, M.D.; et al. Chitosan oligosaccharide (COS): An overview. Int. J. Biol. Macromol. 2019, 129, 827-843. [CrossRef]

78. Huang, R.; Mendis, E.; Rajapakse, N.; Kim, S.K. Strong electronic charge as an important factor for anticancer activity of chitooligosaccharides (COS). Life Sci. 2006, 78, 2399-2408. [CrossRef]

79. Zheng, B.; Wen, Z.S.; Huang, Y.J.; Xia, M.S.; Xiang, X.W.; Qu, Y.L. Molecular weight-dependent immunostimulative activity of low molecular weight chitosan via regulating NF-KB and AP-1 Signaling Pathways in RAW264.7 macrophages. Mar. Drugs 2016, 14. [CrossRef]

80. Ji, X.-G.; Chang, K.-L.; Chen, M.; Zhu, L.-L.; Osman, A.; Yin, H.; Zhao, L.-M. In vitro fermentation of chitooligosaccharides and their effects on human fecal microbial community structure and metabolites. LWT 2021, 144, 111224. [CrossRef]

81. Ibrahim, H.M.; Farid, O.A.; Samir, A.; Mosaad, R.M. Preparation of chitosan antioxidant nanoparticles as drug delivery system for enhancing of anti-cancer drug. Key Eng. Mater. 2018, 759, 92-97. [CrossRef]

82. Lee, H.J.; Park, J.M.; Han, Y.M.; Gil, H.K.; Kim, J.; Chang, J.Y.; Jeong, M.; Go, E.J.; Hahm, K.B. The role of chronic inflammation in the development of gastrointestinal cancers: Reviewing cancer prevention with natural anti-inflammatory intervention. Expert Rev. Gastroenterol. Hepatol. 2016, 10, 129-139. [CrossRef] [PubMed]

83. Santos-Moriano, P.; Kidibule, P.; Míguez, N.; Fernández-Arrojo, L.; Ballesteros, A.O.; Fernández-Lobato, M.; Plou, F.J. Tailored enzymatic synthesis of chitooligosaccharides with different deacetylation degrees and their anti-inflammatory activity. Catalysts 2019, 9, 405. [CrossRef]

84. Yoon, H.J.; Moon, M.E.; Park, H.S.; Im, S.Y.; Kim, Y.H. Chitosan oligosaccharide (COS) inhibits LPS-induced inflammatory effects in RAW 264.7 macrophage cells. Biochem. Biophys. Res. Commun. 2007, 358, 954-959. [CrossRef] [PubMed]

85. Fernandes, J.C.; Spindola, H.; de Sousa, V.; Santos-Silva, A.; Pintado, M.E.; Malcata, F.X.; Carvalho, J.E. Anti-inflammatory activity of chitooligosaccharides in vivo. Mar. Drugs 2010, 8, 1763-1768. [CrossRef]

86. Pangestuti, R.; Bak, S.S.; Kim, S.K. Attenuation of pro-inflammatory mediators in LPS-stimulated BV2 microglia by chitooligosaccharides via the MAPK signaling pathway. Int. J. Biol. Macromol. 2011, 49, 599-606. [CrossRef]

87. Lee, S.-H.; Senevirathne, M.; Ahn, C.-B.; Kim, S.-K.; Je, J.-Y. Factors affecting anti-inflammatory effect of chitooligosaccharides in lipopolysaccharides-induced RAW264.7 macrophage cells. Bioorganic Med. Chem. Lett. 2009, 19, 6655-6658. [CrossRef] 